\title{
Genotypic variability for root/shoot parameters under water stress in some advanced lines of cotton (Gossypium hirsutum L.)
}

\author{
M. Riaz ${ }^{1}$, J. Farooq ${ }^{1}$, G. Sakhawat ${ }^{1}$, A. Mahmood ${ }^{1}$, M.A. Sadiq ${ }^{2}$ and \\ M. Yaseen ${ }^{3}$ \\ ${ }^{1}$ Cotton Research Institute, Ayub Agricultural Research Institute, \\ Faisalabad, Pakistan \\ ${ }^{2}$ Cotton Research Station, Bahawalpur, Pakistan \\ ${ }^{3}$ Cotton Research Institute, Rahim Yar Khan, Pakistan \\ Corresponding authors: J. Farooq / M. Riaz \\ E-mail: drjehanzeb.pbg@gmail.com / riaz_1964@yahoo.com
}

Genet. Mol. Res. 12 (1): 552-561 (2013)

Received March 13, 2012

Accepted October 31, 2012

Published February 27, 2013

DOI http://dx.doi.org/10.4238/2013.February.27.4

\begin{abstract}
Research pertaining to genetic variability parameters, heritability, and genotypic, phenotypic, simple, and environmental correlations for various seedling traits in five elite advanced cotton (Gossypium hirsutum L.) lines (FH-113, FH-114, FH-941, FH-942, and FH-2015) and one check (CIM-496) was carried out during October and November 2010 under greenhouse conditions at the Cotton Research Institute (Faisalabad, Pakistan). Material was raised in plastic tubes with a randomized complete block design replicated three times. Three drought shocks were applied by withholding water from the tube-sown plants for 8-, 10-, and 12-day intervals. After 60 days of sowing, data on root/shoot traits like root length $(\mathrm{cm})$, shoot length $(\mathrm{cm})$, root weight $(\mathrm{g})$, shoot fresh weight $(g)$, lateral root number, root dry weight $(g)$ shoot dry weight $(g)$, and total plant weight $(\mathrm{g})$ were recorded. Considerable genotypic variations existed between genotypes for all seedling characters. Higher broad-sense heritability estimates were found for all traits studied. Maximum broad-
\end{abstract}


sense heritability coupled with high genetic advance in root length $(0.99$, 17.34), lateral root number $(0.91,2.89)$, and shoot length $(0.90,4.35)$ suggested a potential for genetic improvement through breeding and selection. The correlation coefficients among root length, shoot length, root dry weight, fresh shoot weight, and total plant weight were positively and significantly correlated; thus, they can be selected simultaneously as drought tolerance selection indexes owing to the absence of undesired relationships. Genotypes FH-942 and FH-113 had the lowest excised leaf water loss during the first $4 \mathrm{~h}$ and also for the next $4 \mathrm{~h}$. Therefore, these two advanced lines (FH-942 and FH-113) with high initial water content and lower excised leaf water loss had better adaptation to water stress.

Key words: Cotton; Drought; Root; Shoot; Heritability; Correlation coefficients

\section{INTRODUCTION}

Water is one of the most important factors in crop production. Although water is the most plentiful molecule on the surface of the earth, its availability strongly affects terrestrial plant production (Pospíšilová et al., 2000). Water shortage, the major factor limiting plant growth and crop productivity worldwide, is anticipated to increase with the spread of arid lands (Saranga et al., 2001). Furthermore, future climatic changes are expected to increase risks of drought (Rizza et al., 2004). Cotton (Gossypium hirsutum L.) is an important cash crop in Pakistan and is cultivated in warmer climates throughout the country. It sustains millions of people in sectors such as agriculture, textile mills, ginning factories, and business (Imran et al., 2011). The scarcity of irrigation water is increasing in Pakistan and has reduced seed cotton yield per unit area. Water availability is decreasing, and demand for irrigation water is increasing (Reddy et al., 1996). The effect of drought on growth, yield, and quality characters is very serious (Alishah and Ahmadikhah, 2009). Decreasing ground water supply and high-energy costs also affect the production of irrigated cotton. A number of studies have focused on modifying root systems to increase water use efficiency or determining the effects of plant growth regulators on cotton roots for increasing drought resistance (Pace et al., 1999; Howard et al., 2001). Root characteristics can be important in determining the response of plants to drought. Water deficit not only decreases shoot growth rate, plant height, and yield but also affects root growth. However, root growth is less sensitive (McMicheal and Quisenberry, 1991). The variation within species allows the identification of the desired genotypes for the trait(s) in question. Previous research has indicated that variability for drought tolerance in crops is not extensive, but a few studies have shown that variability in the genotypic responses to water stress does occur for example, in wheat (Moinuddin et al., 2005), maize (Kamara et al., 2003), barley (Rizza et al., 2004), and soybean (Hufstetler et al., 2007). These studies have revealed that varieties/cultivars in each species differ from one another in their responses under water stress conditions, suggesting that drought tolerance in these species can be improved through breeding.

The present study aimed to introduce desirable genotypes for commercial cultivation in the Province of Punjab, Pakistan. For this purpose, various exotic germplasm lines with de- 
sirable traits were introduced and established in the gene pool of the Cotton Research Institute (Faisalabad, Pakistan). Five elite advanced lines have been developed by crossing and selection. These lines, in addition to one check variety, were included in this study to evaluate their root/ shoot parameters under water stress conditions. The primary objective of this research was to investigate the differences in these traits among various genotypes under water stress and correlate these parameters to drought tolerance. The second objective was to compare the excised leaf water loss (ELWL) of these genotypes when grown under stressed conditions. This study will help to understand the behavior of genotypes under prevailing environmental conditions.

\section{MATERIAL AND METHODS}

Five advanced lines, namely, FH-113, FH-114, FH-941, FH-942, and FH-2015, along with one check variety, CIM-496, were planted in plastic tubes $(75 \mathrm{~cm}$ tall x $12 \mathrm{~cm}$ wide; filled with fine sand, roots easily washed) in October 2010. Five tubes of each genotype were planted in three replications. Four seeds were sown in each tube, and thinning was carried out to 1 seedling per tube 10 days after germination. The experiment was conducted in a greenhouse of the Cotton Research Institute (Faisalabad, Pakistan) with a $28^{\circ} / 35^{\circ} \mathrm{C}$ night/day temperature and a $40 / 60 \%$ day/night relative humidity. A measured quantity of water was applied to the tubes daily for the first 15 days after sowing. After 15 days, water was stopped for 8, 10, and 12 days. The tubes were fertilized with $2 \%$ liquid NPK thrice during the experimental period. Micronutrients in liquid form (2\%) were also sprayed twice on the 20th and 30th days of the 60 -day experiment. The data for each genotype were recorded 60 days after emergence. Tubes were removed from the greenhouse, and the plants were gently washed to remove all sand. The plants were then spread on paper for determination of root length $(\mathrm{cm})$, total plant weight $(\mathrm{g})$, shoot length $(\mathrm{cm})$, and lateral root number. Plants were cut into roots and shoots, and fresh root weight $(\mathrm{g})$ and fresh shoot weight $(\mathrm{g})$ were measured. The roots and shoots (tap and lateral roots) were dried for $72 \mathrm{~h}$ at $60^{\circ} \mathrm{C}$, and the dry weight was recorded. Genotypes were evaluated for root dry weight and shoot dry weight. Fully expanded third main stem leaves were excised from each replication. Each leaf was immediately weighed for initial leaf weight and then place in a growth room under light at $30^{\circ} \mathrm{C}$ and $45 \%$ relative humidity. The rate of water loss was determined for each leaf blade via weighing at 30-min intervals for $8 \mathrm{~h}$. The samples were dried for $24 \mathrm{~h}$ at $60^{\circ} \mathrm{C}$, and the weight of the dried leaves was measured.

Data obtained from the experiment were analyzed with one-way ANOVA using M Static version IV, and the response of each genotype to the water regimen was evaluated with one-way ANOVA. Heritability in a broad sense was estimated according to the technique of Burton and DeVane (1953). Genetic advance was calculated at $20 \%$ selection intensity ( $\mathrm{i}=1.4$ ), using a formula published by Poehlman and Sleper (1995). All correlations (phenotypic and genotypic) were computed following the statistical technique prescribed by Kowon and Torrie (1964). Genotypic correlations were tested against the double value of standard error of genotypic correlations following the method described by Lothrop et al. (1985). Statistical significance of phenotypic correlations was determined with the $t$-test as described by Steel and Torrie (1984).

\section{RESULTS AND DISCUSSION}

Mean values of all the root/shoot traits are shown in Tables 1 and 2. Line FH-942 
displayed the longest root length $(65 \mathrm{~cm})$, followed by FH-941 $(59.33 \mathrm{~cm}), \mathrm{FH}-113(52.67$ $\mathrm{cm}), \mathrm{FH}-2015(48.67 \mathrm{~cm})$, CIM-496 (40.67 cm), and FH-114 $(30.67 \mathrm{~cm})$. Line FH-114 had the highest lateral root number (21.33), and line CIM-496 had the lowest lateral root number (14.33). Maximum root fresh weight was found in line FH-2015 (0.57 g), followed by FH-942 $(0.55 \mathrm{~g})$. The lowest fresh root weight was seen in line FH-114 (0.39 g). Similar values for maximum dry root weight were found in lines FH-941, FH-942, and FH-2015. In shoot trait measurements, maximum shoot length was shown by lines FH-941, FH-942 (28.67 g) followed by the line FH-2015 (28.33 g). The genotype FH-113 displayed the highest total plant weight $(2.76 \mathrm{~g})$, followed by line FH-941 $(2.21 \mathrm{~g})$. Other lines showed lower plant weights. Line FH-113 had the highest fresh weight and shoot dry weight (2.32 and $0.26 \mathrm{~g}$, respectively).

Table 1. Root characteristics of 5 advanced lines of cotton grown under greenhouse conditions at Cotton Research Institute Faisalabad during 2010.

\begin{tabular}{lcccc}
\hline Genotype & RL $(\mathrm{cm})$ & LRN & RFW (g) & RDW (g) \\
\hline FH-113 & 52.67 & 18.33 & 0.44 & 0.07 \\
FH-114 & 30.67 & 21.33 & 0.39 & 0.06 \\
FH-941 & 59.33 & 19.00 & 0.46 & 0.08 \\
FH-942 & 65.00 & 18.00 & 0.55 & 0.08 \\
FH-2015 & 48.67 & 17.67 & 0.57 & 0.08 \\
CIM-496 & 40.67 & 14.33 & 0.49 & 0.07 \\
\hline
\end{tabular}

$\mathrm{RL}=$ root length; $\mathrm{LRN}=$ lateral root number; $\mathrm{RFW}=$ root fresh weight; $\mathrm{RDW}=$ root dry weight.

Table 2. Shoot characteristics of five advanced lines of cotton grown under greenhouse conditions at Cotton Research Institute Faisalabad during 2010.

\begin{tabular}{lcccc}
\hline Genotype & SL $(\mathrm{cm})$ & TPW $(\mathrm{g})$ & SFW $(\mathrm{g})$ & SDW (g) \\
\hline FH-113 & 27.00 & 2.76 & 2.32 & 0.26 \\
FH-114 & 22.33 & 2.09 & 1.72 & 0.16 \\
FH-941 & 28.67 & 2.21 & 1.74 & 0.18 \\
FH-942 & 28.67 & 2.03 & 1.48 & 0.20 \\
FH-2015 & 28.33 & 1.99 & 1.42 & 0.17 \\
CIM-496 & 21.00 & 1.62 & 1.13 & 0.19 \\
\hline
\end{tabular}

$\mathrm{SL}=$ shoot length $; \mathrm{TPW}=$ total plant weight $\mathrm{SFW}=$ shoot fresh weight $\mathrm{SDW}=$ shoot dry weight.

Nour (1975) grew sorghum plants in pots filled with washed sand for 3 weeks, after which wet root weight, root lengths, volume, and root shoot ratios were measured. The relatively more drought-resistant cultivars had the greatest values for all the four variables. A seedling drought-tolerance protocol was developed as a new method to select drought-tolerant individuals from various genotypes subjected to sequential drought cycles (Longenberger et al., 2006). Iqbal et al. (2010) have studied shoot and root traits under normal water and water stress conditions, and they concluded that the existence of variability in cotton germplasm suggests that genetic improvement can be achieved through selection and breeding provided that the variability is affected by genetic components. Root mass under drought conditions is important in breeding for drought resistance (Hurd and Spratt, 1975). Pace et al. (1999) and Basal et al. (2003) have measured root and shoot 
characteristics in cotton that correlate with drought tolerance. As the number of vascular bundles increased, the height and branching intensities of lateral roots also increased in 7-day-old seedlings of cotton germplasm (McMicheal et al., 1987). Quisenberg et al. (1981) have reported significant variability in tap root length and a number of lateral roots among 35-day-old exotic cotton germplasm grown in a greenhouse. McMicheal and Quisenberg (1991) evaluated growing conditions for exotic cotton genotypes as well as modern cultivars for 60-70 days and found significant differences in root growth and branching. Plant breeders primarily use consistent and absolute cultivars along with public germplasm in developing new cultivars, thereby adding new alleles from exotic genotypes to expand genetic diversity. Liu et al. (2000) have surveyed the molecular variation in 97 cotton race stocks to determine the genetic distance of each race stock from typical $G$. hirsutum cultigens using simple sequence repeat DNA markers.

ANOVA (Table 3) showed a significant difference among the 6 genotypes for all traits studied. The index of transmissibility is used to predict progress from selection. This index, in broad sense, shows the ratio of genetic variance to phenotypic variance. High genetic advance predicts that a character is governed by additive genes and that genetic variance is fixable and selection would improve character (Abbas et al., 2007). Table 3 shows that all parameters had higher broad-sense heritability values. A high transmissibility index of 0.776 to 0.992 indicated that traits were less affected by the environment.

Table 3. Components of variance $(\mathrm{CV})$, heritability $\left(\mathrm{h}^{2}\right)$ and genetic advance $(\mathrm{GA})$ estimates for seedling traits.

\begin{tabular}{|c|c|c|c|c|c|}
\hline Traits & Genotype mean square (d.f. $=49$ ) & Error mean square (d.f. $=98$ ) & $\mathrm{CV} \%$ & $\mathrm{~h}^{2}(\mathrm{BS})$ & GA \\
\hline Root length (cm) & 468.233 & 3.944 & 4.01 & 0.990 & 17.3430 \\
\hline Shoot length $(\mathrm{cm})$ & 35.467 & 3.389 & 7.08 & 0.904 & 4.3537 \\
\hline Lateral root numbers & 15.422 & 1.389 & 6.51 & 0.910 & 2.8884 \\
\hline Fresh root weight $(\mathrm{g})$ & 1.377 & 0.062 & 5.16 & 0.955 & 0.9056 \\
\hline Fresh shoot weight $(\mathrm{g})$ & 0.489 & 0.010 & 6.16 & 0.979 & 0.5537 \\
\hline Total plant fresh weight $(\mathrm{g})$ & 0.419 & 7.294 & 8.07 & 0.930 & 0.4871 \\
\hline Dry shoot weight $(\mathrm{g})$ & 0.405 & 0.091 & 15.73 & 0.861 & 0.8392 \\
\hline Dry root weight $(\mathrm{g})$ & 1.455 & 0.203 & 6.17 & 0.776 & 0.3989 \\
\hline
\end{tabular}

d.f. $=$ degrees of freedom; $\mathrm{BS}=$ broad-sense. All traits were highly significant at $\alpha=1 \%$.

Genetic advance is the expected genetic gain during a single cycle of selection. The maximum values for genetic advance were observed for root length (17.34) and shoot length (4.35), whereas this value was minimal for dry root weight (0.399). Maximum value for root length and shoot length indicated that these characteristics are governed by additive genes and that selection may be effective (Singh and Narayanan, 2000). High transmissibility index for root and shoot length along with the highest genetic advance for these traits showed the presence of additive gene effects (Singh and Narayanan, 2000). Assuming the predominance of additive gene effects, the traits are fixable, and for drought tolerance, selection should be implemented on the basis of these two traits in the present advanced line collection. Similar findings have been reported by Abbas et al. (2007) and Loresto and Chang (1994). In our study, the genotypic, phenotypic (Table 4), and simple 
and environmental (Table 5) correlations were estimated for seedling traits of 6 advanced lines of cotton ( $G$. hirsutum L.). From these correlations at the seedling stage, we predict that drought tolerance and ultimately yield in rapidly growing and deep-rooted genotypes will be higher than those in slowly growing seedlings. Therefore, these correlation coefficient estimates may be used for indirect selection at seedling stages for yield and drought tolerance.

\begin{tabular}{|c|c|c|c|c|c|c|c|c|c|}
\hline Traits & (r) & $\begin{array}{l}\text { Root length } \\
(\mathrm{cm})\end{array}$ & $\begin{array}{l}\text { Shoot } \\
\text { length } \\
(\mathrm{cm})\end{array}$ & $\begin{array}{c}\text { Lateral root } \\
\text { numbers }\end{array}$ & $\begin{array}{l}\text { Fresh root } \\
\text { weight }(\mathrm{g})\end{array}$ & $\begin{array}{c}\text { Fresh shoot } \\
\text { weight }(\mathrm{g})\end{array}$ & $\begin{array}{l}\text { Total plant } \\
\text { fresh } \\
\text { weight }(\mathrm{g})\end{array}$ & $\begin{array}{c}\text { Dry root } \\
\text { weight }(\mathrm{g})\end{array}$ & $\begin{array}{l}\text { Dry shoot } \\
\text { weight }(\mathrm{g})\end{array}$ \\
\hline \multirow[t]{2}{*}{ Root length $(\mathrm{cm})$} & $r(g)$ & 1.0000 & $0.9081^{*}$ & -0.1486 & $0.5747^{*}$ & 0.1528 & $0.2891 *$ & $0.9549 *$ & $0.4489 *$ \\
\hline & $\mathrm{r}(\mathrm{p})$ & 1.0000 & $0.8474 * *$ & -0.1357 & $0.5540^{*}$ & 0.1581 & 0.2874 & $0.8869^{* *}$ & 0.3935 \\
\hline \multirow[t]{2}{*}{ Shoot length $(\mathrm{cm})$} & $r(g)$ & & 1.0000 & $0.2383^{*}$ & $0.5477^{*}$ & $0.3703 *$ & $0.5234^{*}$ & $1.0710^{*}$ & 0.2087 \\
\hline & $\mathrm{r}(\mathrm{p})$ & & 1.0000 & 0.2138 & $0.5247^{*}$ & 0.3288 & 0.4619 & $0.9344^{* *}$ & 0.2233 \\
\hline \multirow[t]{2}{*}{ Lateral root numbers } & $r(g)$ & & & 1.0000 & -0.5180 & $0.5966^{*}$ & $0.5493 *$ & 0.0565 & -0.2168 \\
\hline & $\mathrm{r}(\mathrm{p})$ & & & 1.0000 & $-0.4939 *$ & $0.5528 *$ & $0.4926^{*}$ & 0.0961 & -0.1899 \\
\hline \multirow[t]{2}{*}{ Fresh root weight ( $\mathrm{g}$ ) } & $r(g)$ & & & & 1.0000 & -0.5282 & -0.3844 & $0.6216^{*}$ & -0.1193 \\
\hline & $\mathrm{r}(\mathrm{p})$ & & & & 1.0000 & $-0.5130^{*}$ & -0.3584 & $0.5306^{*}$ & -0.0846 \\
\hline \multirow[t]{2}{*}{ Fresh shoot weight (g) } & $\mathrm{r}(\mathrm{g})$ & & & & & 1.0000 & $1.0000^{*}$ & 0.1549 & $0.7562 *$ \\
\hline & $\mathrm{r}(\mathrm{p})$ & & & & & 1.0000 & $0.9849 * *$ & 0.1239 & $0.6554 * *$ \\
\hline \multirow[t]{2}{*}{ Total plant fresh weight (g) } & $\mathrm{r}(\mathrm{g})$ & & & & & & 1.0000 & 0.3192 & $0.8143^{*}$ \\
\hline & $\mathrm{r}(\mathrm{p})$ & & & & & & 1.0000 & 0.2429 & $0.7026^{* *}$ \\
\hline \multirow[t]{2}{*}{ Dry root weight (g) } & $r(g)$ & & & & & & & 1.0000 & 0.1133 \\
\hline & $\mathrm{r}(\mathrm{p})$ & & & & & & & 1.0000 & 0.0500 \\
\hline \multirow[t]{2}{*}{ Dry shoot weight (g) } & $r(g)$ & & & & & & & & 1.0000 \\
\hline & $\mathrm{r}(\mathrm{p})$ & & & & & & & & 1.0000 \\
\hline
\end{tabular}

\footnotetext{
*Significant at $\alpha=5 \%$;* significant at $\alpha=1 \%$.
}

\begin{tabular}{|c|c|c|c|c|c|c|c|c|c|}
\hline Traits & (r) & $\begin{array}{l}\text { Root } \\
\text { length } \\
(\mathrm{cm})\end{array}$ & $\begin{array}{l}\text { Shoot } \\
\text { length } \\
(\mathrm{cm})\end{array}$ & $\begin{array}{l}\text { Lateral root } \\
\text { numbers }\end{array}$ & $\begin{array}{l}\text { Fresh root } \\
\text { weight }(\mathrm{g})\end{array}$ & $\begin{array}{c}\text { Fresh shoot } \\
\text { weight }(\mathrm{g})\end{array}$ & $\begin{array}{l}\text { Total plant } \\
\text { fresh } \\
\text { weight }(\mathrm{g})\end{array}$ & $\begin{array}{c}\text { Dry root } \\
\text { weight }(\mathrm{g})\end{array}$ & $\begin{array}{l}\text { Dry shoot } \\
\text { weight }(\mathrm{g})\end{array}$ \\
\hline \multirow[t]{2}{*}{ Root length $(\mathrm{cm})$} & $\mathrm{r}(\mathrm{s})$ & 1.0000 & $0.7289 * *$ & -0.1056 & $0.5110^{*}$ & 0.1701 & 0.2855 & $0.7627 * *$ & 0.3167 \\
\hline & $\mathrm{r}(\mathrm{e})$ & 1.0000 & -0.4445 & 0.1958 & -0.2635 & 0.5659 & 0.4027 & 0.1382 & 0.0132 \\
\hline \multirow[t]{2}{*}{ Shoot length $(\mathrm{cm})$} & $r(s)$ & & & 0.1748 & $0.5224 *$ & 0.2509 & 0.3707 & $0.7195^{* *}$ & 0.2011 \\
\hline & $\mathrm{r}(\mathrm{e})$ & & & 0.0256 & 0.2389 & -0.4418 & -0.2256 & -0.0905 & 0.3313 \\
\hline \multirow[t]{2}{*}{ Lateral root numbers } & $\mathrm{r}(\mathrm{s})$ & & & & 0.4376 & -0.4679 & 0.4030 & 0.1528 & -0.1593 \\
\hline & r (e) & & & & -0.1737 & -0.2391 & -0.0998 & 0.4117 & -0.0546 \\
\hline \multirow[t]{2}{*}{ Fresh root weight (g) } & $r(s)$ & & & & & $-0.4768^{*}$ & -0.2751 & 0.3786 & -0.5045 \\
\hline & $\mathrm{r}(\mathrm{e})$ & & & & & -0.0672 & 0.0704 & -0.4139 & 0.1794 \\
\hline \multirow{2}{*}{ Fresh shoot weight (g) } & $\mathrm{r}(\mathrm{s})$ & & & & & & $0.9582 * *$ & 0.0687 & $0.5045^{*}$ \\
\hline & $\mathrm{r}(\mathrm{e})$ & & & & & & 0.7985 & -0.3396 & -0.0521 \\
\hline \multirow[t]{2}{*}{ Total plant fresh weight (g) } & $\mathrm{r}(\mathrm{s})$ & & & & & & & 0.1167 & $0.5088 *$ \\
\hline & $\mathrm{r}(\mathrm{e})$ & & & & & & & -0.4345 & 0.0874 \\
\hline \multirow[t]{2}{*}{ Dry root weight (g) } & $\mathrm{r}(\mathrm{s})$ & & & & & & & & -0.0520 \\
\hline & $\mathrm{r}(\mathrm{e})$ & & & & & & & & -0.2406 \\
\hline \multirow[t]{2}{*}{ Dry shoot weight (g) } & $r(s)$ & & & & & & & & 1.0000 \\
\hline & r (e) & & & & & & & & 1.0000 \\
\hline
\end{tabular}

*Significant at $\alpha=5 \% ; * *$ significant at $\alpha=1 \%$.

Phenotypic correlations for root length-shoot length, root length-root dry weight, shoot length-root dry weight, fresh shoot weight-total plant fresh weight and shoot dry weight, and root dry weight-shoot dry weight were positive and highly significant. Simi- 
larly, genotypic correlation for these traits was positive and significant, indicating the need for scope of selection (Sandhu and Kang, 1998). Subburamu et al. (1998) also reported that yield was significantly and positively correlated with shoot length. Similarly, Natarajan (1992) and Abbas et al. (2007) showed that yield was positively and significantly correlated with leaf area, root length, and dry root weight in tomato. Similar findings have been reported by Viera et al. (1995).

Simple correlation among the root/shoot parameters of advanced lines revealed that root length exhibited a positive relationship with shoot length and fresh and dry root weight. Similarly, shoot lengths were also positively and significantly associated with fresh and dry root weight. In the same way, strong positive association existed among fresh shoot weight, dry shoot weigh, and total fresh plant weight. These results showed that shoot weight contributed more positively to total plant weight under water stress conditions. Conversely, a significant negative correlation was found between fresh root weight and fresh shoot weight, suggesting that root length, shoot length, fresh root weight, and dry shoot weight can be chosen simultaneously as water stress tolerance selection criteria, as no unwanted relationship was apparent among them. Basal et al. (2003) studied seedling root/shoot parameter variability among genotypes. A number of morphophysiological traits such as distance from the transition zone to the first main lateral root, tap root weight, the number of lateral roots, seedling vigor, sensitivity of root system development, root-toshoot ratio (Cook, 1985), long tap root length (Pace et al., 1999; Ali et al., 2011), and leaf water content (Leidi et al., 1999) have been suggested to be important in cotton.

ANOVA revealed significant genetic variation among various genotypes of cotton with respect to initial water content (IWC) and lower ELWL after a 30-min interval for $8 \mathrm{~h}$ and after $24 \mathrm{~h}$ (Table 6). Mean comparisons (Table 7) showed that FH-942 had the highest initial excised leaf water content, followed by FH-113, FH-114, FH-2015, and FH-941, whereas the lowest IWC occurred in CIM-496. The rate of water loss through transpiration from excised leaves differed among the 6 genotypes for the first $4 \mathrm{~h}$ : it was lowest in FH-942 at $30 \mathrm{~min}$ followed by FH-113 (30 min); FH-2015 (60 min); FH-114 (90 min); FH-2015, FH-942, and FH-113 (120 min); FH-2015 and FH-113 (150 min); FH-113 and FH-2015 (180 min); FH-2015 and FH-113 (210 and 240 min, respectively); FH-113 and CIM-496 (270-300 $\mathrm{min}$ ), and FH-942 and CIM-496 (480 min). After $24 \mathrm{~h}$, the ELWL of FH-942 and FH-113 were found to be 2.100 and $2.200 \mathrm{mg} \mathrm{H}_{2} \mathrm{O} \cdot 30 \mathrm{~m}^{-1} \cdot \mathrm{mg}$ dry weight ${ }^{-1}$, respectively (Quisenberry, 1982). Thus, the data imply that genotypic differences exist for IWC and ELWL. Reducing water loss through transpiration by closing stomata is a short-term response of plants under water stress condition (Mansfield et al., 1990). Therefore, our results indicate that genotypes FH-942 and FH-113 - having high IWC and low ELWL - exhibited better adaptation to water deficit conditions. Information from these experiments demonstrated genotypic differences for IWC and ELWL. Clarke et al. (1989) have reported that accessions with low rates of water loss from excised leaves had higher yields than those of accessions with higher rates of water loss from excised leaves when grown under water-limited conditions. Excised leaf water loss had been widely used as a selection parameter for drought tolerance in various crop plants (Bhutta, 2007; Ali et al., 2009). If an extensive root system can be combined with the capability of maintaining high leaf water content, the resulting genotype may have superior adaptation to dry land environments. These inferences have also been drawn by Hurd and Spratt (1975). 
Table 6. Mean squares for initial water content (IWC) and excised leaf water loss (ELWL) at 30-min intervals.

\begin{tabular}{|c|c|c|c|c|c|c|c|c|c|c|}
\hline \multirow[t]{2}{*}{ Source } & \multirow[t]{2}{*}{ d.f. } & \multirow{2}{*}{$\begin{array}{c}\text { IWC }\left(\mathrm{mg} \mathrm{H}_{2} \mathrm{O} / \mathrm{mg}\right. \\
\text { dry weight) }\end{array}$} & \multicolumn{8}{|c|}{ ELWL $\left(\mathrm{mg} \mathrm{H}_{2} \mathrm{O} \cdot 30 \mathrm{~m}^{-1} \cdot \mathrm{mg}\right.$ dry weight $\left.{ }^{-1}\right)$} \\
\hline & & & $30 \mathrm{~min}$ & $60 \mathrm{~min}$ & $90 \mathrm{~min}$ & $120 \mathrm{~min}$ & $150 \mathrm{~min}$ & $180 \mathrm{~min}$ & $210 \mathrm{~min}$ & $240 \mathrm{~min}$ \\
\hline Replications & 2 & $0.04251^{* *}$ & $0.00042 * *$ & $0.00109^{* *}$ & $0.00037^{* *}$ & $0.00121^{* *}$ & $0.00612 * *$ & $0.00182^{* *}$ & $0.00184^{* *}$ & $0.00116^{* *}$ \\
\hline Genotypes & 5 & $0.0172 * *$ & $0.09537 * *$ & $0.03533^{* *}$ & $0.04001 * *$ & $0.02624 * *$ & $0.05601 * *$ & $0.05601 * *$ & $0.02857 * *$ & $0.04192 * *$ \\
\hline Error & 10 & 0.00943 & 0.00138 & 0.00040 & 0.00144 & 0.00154 & 0.00190 & 0.00182 & 0.00335 & 0.00155 \\
\hline \multirow[t]{2}{*}{ Source } & d.f. & \multicolumn{9}{|c|}{ ELWL $\left(\mathrm{mg} \mathrm{H}_{2} \mathrm{O} \cdot 30 \mathrm{~m}^{-1} \cdot \mathrm{mg}\right.$ dry weight $\left.{ }^{-1}\right)$} \\
\hline & & $270 \mathrm{~min}$ & $300 \mathrm{~min}$ & $330 \mathrm{~min}$ & $360 \mathrm{~min}$ & $390 \min$ & $420 \mathrm{~min}$ & $450 \mathrm{~min}$ & $480 \mathrm{~min}$ & $24 \mathrm{~h}$ \\
\hline Replications & 2 & $0.00152 * *$ & $0.00336 * *$ & $0.00062 *$ & $0.00637^{* * *}$ & $0.00155^{* *}$ & $0.00174 * *$ & $0.00065^{* * *}$ & $0.00261 * *$ & $0.04055^{* *}$ \\
\hline Genotypes & 5 & $0.05528 * *$ & $0.03417 * *$ & $0.00902 * *$ & $0.05135^{* *}$ & $0.06934 * *$ & $0.05698 * *$ & $0.06157 * *$ & $0.05006^{* *}$ & $0.0336 * *$ \\
\hline Error & 10 & 0.00328 & 0.00634 & 0.00479 & 0.00421 & 0.00350 & 0.00177 & 0.00329 & 0.00283 & 0.00737 \\
\hline
\end{tabular}

d.f. $=$ degrees of freedom. *Significant at $\alpha=5 \%$; ** significant at $\alpha=1 \%$.

Table 7. Initial water content (IWC) and excised leaf water loss (ELWL) at 30-min intervals.

\begin{tabular}{|c|c|c|c|c|c|c|c|c|c|}
\hline \multirow[t]{2}{*}{ Genotypes } & \multirow[t]{2}{*}{ IWC ( $\mathrm{mg} \mathrm{H}_{2} \mathrm{O} / \mathrm{mg}$ dry weight) } & \multicolumn{8}{|c|}{ ELWL $\left(\mathrm{mg} \mathrm{H}_{2} \mathrm{O} \cdot 30 \mathrm{~m}^{-1} \cdot \mathrm{mg}\right.$ dry weight $\left.{ }^{-1}\right)$} \\
\hline & & $30 \mathrm{~min}$ & $60 \mathrm{~min}$ & $90 \mathrm{~min}$ & $120 \mathrm{~min}$ & $150 \mathrm{~min}$ & $180 \mathrm{~min}$ & $210 \mathrm{~min}$ & $240 \mathrm{~min}$ \\
\hline FH-113 & $3.260^{\mathrm{ab}}$ & $0.183^{\mathrm{c}}$ & $0.417^{\mathrm{c}}$ & $0.487^{\mathrm{bc}}$ & $0.543^{\mathrm{c}}$ & $0.667^{\mathrm{d}}$ & $0.667^{\mathrm{d}}$ & $0.733^{\mathrm{cd}}$ & $0.733^{\mathrm{c}}$ \\
\hline FH-114 & $3.250^{\mathrm{ab}}$ & $0.273^{\mathrm{b}}$ & $0.357^{\mathrm{d}}$ & $0.357^{\mathrm{d}}$ & $0.633^{\mathrm{b}}$ & $0.910^{\mathrm{a}}$ & $0.910^{\mathrm{a}}$ & $0.910^{\mathrm{a}}$ & $0.910^{\mathrm{ab}}$ \\
\hline FH-941 & $3.200^{\mathrm{b}}$ & $0.490^{\mathrm{a}}$ & $0.463^{\mathrm{b}}$ & $0.543^{\mathrm{b}}$ & $0.667^{\mathrm{b}}$ & $0.807^{\mathrm{bc}}$ & $0.807^{\mathrm{bc}}$ & $0.807^{\mathrm{abc}}$ & $0.947^{\mathrm{a}}$ \\
\hline FH-942 & $3.330^{\mathrm{ab}}$ & $0.000^{\mathrm{d}}$ & $0.320^{\mathrm{e}}$ & $0.433^{\mathrm{c}}$ & $0.557^{\mathrm{c}}$ & $0.770^{\mathrm{c}}$ & $0.770^{c}$ & $0.770^{\mathrm{bc}}$ & $0.770^{\mathrm{c}}$ \\
\hline FH-2015 & $3.223^{\mathrm{ab}}$ & $0.210^{\mathrm{bc}}$ & $0.213^{\mathrm{f}}$ & $0.437^{\mathrm{c}}$ & $0.537^{\mathrm{c}}$ & $0.537^{\mathrm{e}}$ & $0.537^{\mathrm{a}}$ & $0.633^{\mathrm{d}}$ & $0.633^{\mathrm{d}}$ \\
\hline CIM-496 & $3.320^{\mathrm{a}}$ & $0.433^{\mathrm{a}}$ & $0.517^{\mathrm{a}}$ & $0.690^{\mathrm{a}}$ & $0.777^{\mathrm{a}}$ & $0.860^{\mathrm{ab}}$ & $0.860^{\mathrm{ab}}$ & $0.860^{\mathrm{ab}}$ & $0.860^{\mathrm{b}}$ \\
\hline \multirow[t]{2}{*}{ Genotypes } & \multicolumn{9}{|c|}{ ELWL $\left(\mathrm{mg} \mathrm{H}_{2} \mathrm{O} \cdot 30 \mathrm{~m}^{-1} \cdot \mathrm{mg}\right.$ dry weight $\left.{ }^{-1}\right)$} \\
\hline & $270 \mathrm{~min}$ & $300 \mathrm{~min}$ & $330 \mathrm{~min}$ & $360 \mathrm{~min}$ & $390 \mathrm{~min}$ & $420 \mathrm{~min}$ & $450 \mathrm{~min}$ & $480 \mathrm{~min}$ & $24 \mathrm{~h}$ \\
\hline FH-113 & $0.733^{\mathrm{c}}$ & $0.733^{\mathrm{c}}$ & $0.863^{\mathrm{b}}$ & $0.863^{\mathrm{e}}$ & $0.983^{\mathrm{e}}$ & $0.983^{\mathrm{d}}$ & $0.983^{\mathrm{d}}$ & $1.160^{\mathrm{c}}$ & $2.200^{\mathrm{c}}$ \\
\hline FH-114 & $0.910^{\mathrm{ab}}$ & $0.910^{\mathrm{ab}}$ & $0.910^{\mathrm{ab}}$ & $1.183^{\mathrm{ab}}$ & $1.263^{\mathrm{b}}$ & $1.263^{\mathrm{c}}$ & $1.130^{\mathrm{b}}$ & $1.263^{\mathrm{b}}$ & $2.333^{\mathrm{ab}}$ \\
\hline FH-941 & $0.947^{\mathrm{ab}}$ & $1.037^{\mathrm{a}}$ & $1.023^{\mathrm{a}}$ & $1.027^{\mathrm{cd}}$ & $1.173^{\mathrm{bc}}$ & $1.173^{\mathrm{b}}$ & $1.237^{\mathrm{bc}}$ & $1.237^{\mathrm{bc}}$ & $2.203^{\mathrm{bc}}$ \\
\hline FH-942 & $0.987^{\mathrm{a}}$ & $0.987^{\mathrm{ab}}$ & $0.97^{\mathrm{ab}}$ & $1.112^{\mathrm{a}}$ & $1.122^{\mathrm{a}}$ & $1.125^{\mathrm{a}}$ & $1.133^{\mathrm{a}}$ & $1.135^{\mathrm{a}}$ & $2.100^{\mathrm{d}}$ \\
\hline FH-2015 & $0.633^{\mathrm{c}}$ & $0.947^{\mathrm{ab}}$ & $0.947^{\mathrm{ab}}$ & $1.077^{\mathrm{bc}}$ & $1.047^{\mathrm{de}}$ & $1.047^{\mathrm{c}}$ & $1.157^{\mathrm{cd}}$ & $1.157^{\mathrm{c}}$ & $2.350^{\mathrm{ab}}$ \\
\hline CIM-496 & $0.860^{\mathrm{b}}$ & $0.860^{\mathrm{bc}}$ & $0.943^{\text {ab }}$ & $0.943^{\text {de }}$ & $1.120^{\mathrm{cd}}$ & $1.120^{\mathrm{bc}}$ & $1.197^{\mathrm{bcd}}$ & $1.203^{\mathrm{bc}}$ & $2.390^{\mathrm{a}}$ \\
\hline
\end{tabular}

Means within column followed by the same superscript letters are not different at critical $\mathrm{T}$ value $=2.228$, according to the LSD test.

Success in drought-tolerant plant development programs is mostly based on the identification of drought parameters in a genotype and the selection of these promising genotypes for cultivar development. The information regarding genetic variability and correlation with desirable traits provides a reliable basis for crop improvement. Using our results and those of the studies cited herein, we concluded that the advanced line FH-942 has high genetic potential and space for excellent performance under water stress conditions.

\section{REFERENCES}

Abbas G, Ali A, Saeed A, Hussnain H, et al. (2007). Estimation of Heritability and Correlations Analysis for Seed Testing in Various Accessions of Tomato. Proceedings: International Symposium on Prospects of Horticultural Industry in Pakistan.

Ali MA, Abbas A, Niaz S, Zulkiffal M, et al. (2009). Morpho-physiological criteria for drought tolerance in Sorghum (Sorghum bicolor) at seedling and post-anthesis stages. Int. J. Agric. Biol. 11: 674-680.

Ali MA, Jabran K, Awan SI, Abbas A, et al. (2011). Morpho-physiological diversity and its implications for improving drought tolerance in grain sorghum at different growth stages. Aust. J. Crop. Sci. 5: 311-320.

Alishah O and Ahmadikhah A (2009). The Effects of Drought Stress on Improved Cotton Varieties in Golesatn Province 
of Iran. Int. J. Plant Prod. 3: 17-26.

Basal H, Bebeli P, Smith CW and Thaxton P (2003). Root growth parameters of converted race stocks of upland cotton and two $\mathrm{BC}_{2} \mathrm{~F}_{2}$ population. Crop Sci. 43: 1983-1988.

Bhutta WM (2007). The effect of cultivar on the variation of spring wheat grain quality under drought conditions. Cereal Res. Coтmum. 35: 1609-1619.

Burton GW and DeVane EH (1953). Estimating heritability in tall Fescue (Festuca arundinacea) from replicated clonal material. Agron. J. 45: 478-481.

Clarke JM, Romagosa I, Jana S, Srivastava JP, et al. (1989). Relationship of excise-leaf water loss rate and yield of durum wheat in diverse environment. Can. J. Plant Sci. 69: 1075-1081.

Cook CG (1985). Identifying Root Traits Among MAR and Non-MAR Cotton, Gossypium Hirsutum L. Cultivars that Relate to Performance Under Limited Moisture Conditions. Master's thesis, Texas A \& M University, College Station, Texas.

Howard DD, Gwathney CO, Lessman GM and Roberts RK (2001). Fertilizer additive rate and plant growth regulator effects on cotton. J. Cotton Sci. 5: 42-52.

Hufstetler VE, Boerma R, Carter TE Jr and Earl HJ (2007). Genotypic variation for three physiological traits affecting drought tolerance in soybean. Crop Sci. 47: 25-35.

Hurd EA and Spratt ED (1975). Root Pattern in Crops Related to Water and Nutrition Uptake. Physiological Aspects of Dry Land Farming (Gupta US, ed.). Oxford \& IBH Publ. Co., New Delhi.

Imran M, Shakeel A, Farooq J, Saeed A, et al. (2011). Genetic studies of fiber quality parameter and earliness related traits in upland cotton (Gossypium hirsutum L.). Adv. Agric. Bot. 3: 151-159.

Iqbal K (2010). The Potential for Breeding Upland Cotton Under Limited Water Conditions. PhD thesis, UAF, Faisalabadd.

Kamara AY, Menkir A, Babu-Apraku B and Ibikunle O (2003). The influence of drought stress on growth, yield and yield components of stressed maize genotypes. J. Agric. Sci. 141: 43-50.

Kwon SH and Torrie JH (1964). Heritability and inter relationship of traits of two soybean populations. Crop Sci. 4: 194-196.

Leidi EO, Lopez M, Gorham J and Gutierrez JC (1999). Variation in carbon isotope discrimination and other traits related to drought tolerance in upland cotton cultivars under dryland conditions. Field Crops Res. 61: 109-123.

Liu S, Cantrell RG, McCarty JC and Stewart JM (2000). Simple sequence repeat-based assessment of genetic diversity in cotton race stock accessions. Crop Sci. 40: 1459-1469.

Longenberger PS, Smith CW, Thaxton P, Marla B, et al. (2006). Development of a screening method for drought tolerance in cotton seedlings. Crop Sci. 46: 2104-2110.

Loresto GC and Chang TT (1994). Genetic control of rice root system associated with drought resistance. Spec. Publ. Taichung District Agr. Improvement Station 35: 77-83.

Lothrop JE, Atkins RE and Smith OS (1985). Variability of yield and yield components in IAPIR grain sorghum randommating populations. I. Means, variance components and heritabilities. Crop Sci. 25: 235-240.

Mansfield TA, Hetherington AM and Atkinson CJ (1990). Some current aspects of stomatal physiology. Ann. Rev. Plant Physiol. Plant Mol. Biol. 41: 55-75.

McMichael BL and Quisenberry JE (1991). Genetic variation for root - shoot relationship among cotton germplasm. Environ. Exp. Bot. 31: 461-470.

McMicheal BL, Quisenberry JE and Upchruch DR (1987). Lateral root development in exotic cottons. Environ. Exp. Bot. 27: 499-502.

Moinuddin, Fischer RA, Sayre KD and Reynolds MP (2005). Osmotic adjustment in wheat in relation to grain yield under water deficit environments. Agron. J. 97: 1062-1071.

Natarajan S (1992). Genetic variability and association of leaf area, root length and root dry weight: shoot dry weight ratio in tomato under moisture stress. Madras Agric. J. 79: 271-276.

Nour AM (1975). Some Aspects of Drought Resistance in Grain Sorghum. PhD. thesis, Oklahoma State University, Stillwater.

Pace PF, Cralle HT, El-Halawany SHM, Cothren JT, et al. (1999). Drought induced changes in root and shoot growth of young cotton plants. J. Cotton Sci. 3: 183-187.

Poehlman JM and Sleper DA (1995). Breeding Field Crops. Panima Publishing Corporation, New Delhi.

Pospíšilová J, Synková H and Rulcová J (2000). Cytokinins and water stress. Biol. Plant. 43: 321-328.

Quisenberry JE (1982). Use of transpiration decline curves to identify drought tolerance cotton germplasm. Crop Sci. 22: 918-922.

Quisenberry JE, Jordan WR, Roark BA and Fryrear DW (1981). Exotic cottons as genetic sources for drought resistance. Crop Sci. 21: 888-959.

Reddy KR, Hodges HF and McKinion JM (1996). Food and agriculture in the 21st century: a cotton example. World Res. Rev. 8: 80-97. 
Rizza F, Badeck FW, Cattivelli L, Lidestri O, et al. (2004). Use of a water stress index to identify barley genotypes adapted to rainfed and irrigated conditions. Crop Sci. 44: 2127--2137.

Sandhu SK and Kang GS (1998). Genetic analysis in germplasm of andigena potatos (Solanum tuberosum subspecies Andigena). Crop Improvement 25: 181-185.

Saranga Y, Menz M, Jiang CX, Wright RJ, et al. (2001). Genomic dissection of genotype x environment interactions conferring adaptation of cotton to arid conditions. Genome Res. 11: 1988-1995.

Singh P and Narayanan SS (2000). Biometrical Techniques in Plant Breeding. 2nd edn. Kalyani Publishers, New Delhi.

Steel RDG and Torrie JH (1984). Principles and Procedures of Statistics. McGraw Hill Book Co. Inc., New York.

Subburamu K, Jayapragasam M and Thandapani V (1998). Heterosis for seed and seedling characters in tomato (Lycopersicon esculentum Mill.). Seed Res. 26: 187-190.

Vieira RM, Bourland FM and Watson CERJ (1995). Relationships and Inheritance of Selected Seedling Vigour Parameters in Cotton. In: Beltwide Cotton Conference. National Cotton Council, Memphis, 507-510. 